\title{
THE UNCHARTED TERRITORY IN UNCHARTED 3: EXPECTANCY VS. PROFESSIONAL NORMS IN TRANSLATED GAMES*
}

\section{O INEXPLORADO EM UNCHARTED 3: NORMAS DE EXPECTATIVA VERSUS NORMAS PROFISSIONAIS EM GAMES TRADUZIDOS}

\author{
Marileide Dias ESQUEDA \\ Universidade Federal de Uberlândia \\ Instituto de Letras e Linguística \\ Bacharelado em Tradução \\ Uberlândia, Minas Gerais, Brasil \\ orcid.org/0000-0002-6941-7926 \\ marileide.esqueda@ufu.br
}

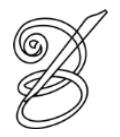

\author{
Bárbara Coelho MELO \\ Pesquisadora autônoma \\ Uberlândia, Minas Gerais, Brasil \\ orcid.org/0000-0003-2090-5969 \\ barbara.resende.coelho@gmail.com
}

\begin{abstract}
Game localization and translation have an intricate connection with global business and marketing operations, allowing these products to cross complex sociocultural and linguistic borders and reach players from a growing variety of territories (O’Hagan and Mangiron, 2013). Aware of the diversity of its target audience and the profit provided by the distribution of its products in these locales, the game industry has increasingly invested in localization and translation for its titles. Although this is still a relatively new strategy, game localization and translation already witness the impact of expectancy and professional norms (Chesterman, Memes of Translation, "Bridge Concepts in Translation Sociology"). This study aimed to investigate how these norms operate and converge by analyzing the game Uncharted 3: Drake's Deception and the comments made by players about its fully localized version in Brazilian Portuguese. The results obtained from the analysis of gameplay and comments shed light on the relationship between expectancy and professional norms across the agents involved in the localization and translation of this sort of materials, which allowed for a better understanding both of what Brazilian users expect from a translated game and of what is actually done according to the professional norms. Keywords: Localization and translation. Expectancy norms. Professional norms. Uncharted 3: Drake's Deception. Translation users.

Resumo: A tradução e localização de games têm uma intrincada conexão com operações globais de negócios e marketing, o que permite que esses produtos atravessem complexas fronteiras socioculturais e linguísticas e cheguem até jogadores de uma crescente gama de territórios (O'Hagan and Mangiron). Cientes da diversidade de seu público-alvo e do lucro proporcionado pela distribuição de seus produtos nesses mercados, a indústria de games tem, cada vez mais, investido em localizações e traduções para seus títulos. Ainda que se trate de uma prática relativamente nova, a localização e tradução de games já sentem os efeitos das normas de expectativa dos usuários (Chesterman, Memes of Translation, "Bridge Concepts in Translation Sociology"). Nessa perspectiva, este estudo buscou investigar como essas normas se evidenciam em comentários tecidos por gamers a respeito da versão totalmente localizada para o português do Brasil do jogo Uncharted 3: Drake's Deception. Os resultados obtidos por meio da análise dos comentários dos gamers e do gameplay capturado elucidaram a relação entre normas de expectativa e profissionais dos agentes envolvidos na localização e tradução desse material, possibilitando compreender o que os usuários brasileiros esperam de um game traduzido e o que é, de fato, feito de acordo com as normas profissionais.
\end{abstract}

Palavras-chave: Tradução e localização de games. Normas de expectativa. Normas profissionais. Uncharted 3: Drake's Deception. Usuários de tradução. 


\section{Introduction}

ame $^{1}$ localization refers to the several different processes involved in transforming
an entertainment software (i.e. a game) into a product adapted to distinct target
markets (locales or countries), whose users possess a set of linguistic, cultural, and technical characteristics that are different from those of the place where the product was originally conceived (O’Hagan and Mangiron). Game localization differs from software localization (see Sandrini) and website localization (see Jiménez-Crespo), as games are not utilitarian products; rather, they are affective media that provide an environment where, thanks to the interactivity allowed by this kind of software, the player feels emotionally connected to the outcome of the game, using features such as creating their own avatar, adjusting their individual skills, saving their progress, and progressing at their own pace (Bernal-Merino). In addition, games are not only technological artifacts, but also products that represent symbolic cultural meanings and have a deep effect on society through its production and use.

A game can receive different levels of localization depending on its content. Choosing one of the localization levels (Dunne) presented below depends on the game's developer, producer, and publisher, as well as its budget and sales perspective in each target market (O’Hagan and Mangiron).

Chandler and Deming classify the levels of localization as follows:

1) games with no localization: the game is retailed in all markets in its original form, without any financial investment in localization,

2) box and docs localization: the packaging and manual of the game are translated and adjusted to the local legislation, but the code and language of the game remain unchanged. This approach is generally used for games with little linguistic content, titles with a low sales perspective, or games that will be sold in places where the target demographic has a high proficiency in the source language. This was also a common approach in the earliest days of the game industry,

3) partial localization: the in-game text is translated, but any voiceover content is left unchanged, reducing the time and budget required to produce the localized versions. The voice files generally receive subtitles in the target language, 
4) full localization/full-loc: this level comprises the translation of all game components, such as text, dialogues, manuals, and packaging. It is the most expensive type of localization and is generally adopted for AAA games (titles with big production budgets and a high estimated financial return). Some full localizations include other levels of adaptation for the target market, such as changes in the characters, story, and other non-linguistic features of the game. However, this approach is very expensive and involves changes in the source code, thus being seldomly adopted.

When it comes to the translation of the content of the game, the marketing departments look for what is considered popular in the target market (Bernal-Merino), taking into account what fans say in official websites or informal comment sections to select translation strategies, which, as stated by Venuti, vary in the amount of foreignization they employ (Souza, "Venuti e os Videogames", "Video Game Localization").

The main goal of game localization is to provide the final users of the target market with the same potential of gameplay experience of the original (O’Hagan and Mangiron). This close relationship between the industry and the final user, which is characteristic of game localization and sets it apart from other types of localization, makes it necessary for the translation, as part of this process, to enable interactivity, for it is through textual language that the player-game communication and interaction occur, from the game's menu and controls to the actual content and character dialogue (when applicable).

In fact, the content of the game needs to be properly translated so that the result is satisfactory and functional in the opinion of the users (O'Hagan and Mangiron). Although this requirement may be considered a sort of creative freedom, it is usually accompanied by restrictions imposed by developers and publishers. The expectations regarding the form and role of translation, the norms of the society in which it is inserted, and the very concept of translator and translation are just a few of the many restrictions that may influence the translation process (Kiraly).

However, even when pursuing such a goal, due to factors like short deadlines, firm international release dates, as well as the small grasp most people have on game localization, the reality of translated and localized games is that this type of translation often lacks the same quality of the original product, falling short of the expectations of the developers, translators, 
and players. As a result, many users of full-loc versions turn to blogs and gaming forums to voice their complaints about mistranslations and other errors (Bernal-Merino).

Developers, critics and gamers have been increasingly vocal about the quality of game translation, expressing their opinions in personal notes and official information (O'Hagan and Mangiron). This has brought about a vast range of online resources in the form of game reviews, blogs, and message boards, providing a rich collection of data for researchers of the field (O’Hagan and Mangiron).

The quote included in the introduction of this paper, spoken by YouTube gamer ${ }^{2}$ BRKsEDU in one of his gameplay videos ${ }^{3}$ of Uncharted 3: Drake's Deception, is a good example of some of the criticism received by this type of material, and it is a representation of the expectancy norms shared by many users of games translated into Brazilian Portuguese (hereinafter PT-BR). This sort of comment, "Dude, nobody says 'barbada'. Why does a translator use these words, you know?" (our translation), can shed some light on how the user perceives the role played by translation and the translator in the localization process.

The aim of this paper is to investigate the expectancy norms (Chesterman, "Bridge 176 Concepts in Translation Sociology", Memes of Translation) regarding the PT-BR translation of the game Uncharted 3: Drake's Deception as manifested by Brazilian players in blogs, message boards, websites, and YouTube channels. Such an investigation is expected to provide a better understanding of this aspect that is majorly relevant for shaping a practice that has yet to be consolidated and that, by definition, is targeted at the end user.

Chesterman points out that research using sociological approaches has been mainly focused on people and their observable actions ("Bridge Concepts in Translation Sociology"). Therefore, this study employs the causal model presented by the author, i.e., a model that seeks to reveal relations of cause and effect. Under this perspective, game translation is seen as being caused or influenced by several causal conditions, while also being the cause of effects (e.g., the opinion of clients/users about its quality). Causal models link some textual features in translations to external factors, which are presumed to be causal conditions or resulting effects:

\footnotetext{
In terms of a simple causal chain, for instance, we could say: this translation is like this, it contains these particular features, because of the decisions that this translator took; the translator worked like that partly because of the nature of the source text, the client's instructions and the ridiculously short deadline; the client specified these conditions because of the norms governing translation work of this kind in this society at this time, which are themselves determined e.g. by commercial values. (Chesterman, "Bridge Concepts in Translation Sociology", 175)
} 
With this research, we seek to gain a better understanding of the norms that govern the formation of opinion of the users in regard to a translated (and especially dubbed) game, the conflicting opinions among different users, and how these expectations converge (or not) with the professional norms (Chesterman, "Bridge Concepts in Translation Sociology", Memes of Translation) of game translation, which will also be discussed in this paper.

\section{Methodology}

Given the fact that this is a descriptive study of sociological nature (O'Hagan and Mangiron), this study was carried out in two stages: the first stage comprised the collection of user comments for the discussion of expectancy norms, while the second stage consisted of recording the gameplay of the video game Uncharted 3: Drake's Deception, aiming to investigate the professional norms for this type of entertainment media.

First, we looked at blogs, message boards, websites, and YouTube channels in search of comments addressing the translation aspect of the PT-BR dubbed version of the game. After scanning these sharing tools of online content, we selected the sources that held more relevance for the aims of this study, excluding those that were too vague or too repetitive. As such, the comments were obtained from Eurogamer.pt, a Portuguese website that publishes news articles about games and that is widely accessed by Brazilian players, as well as from four YouTube gaming channels that published the complete gameplay of Uncharted 3 in its dubbed version in Brazilian Portuguese: BRKsEDU, Gabrielprimeiro, Lucky Salamander, and Sinxplaysbr. These comments were later categorized, as will be shown further on.

The decision to collect pre-existing comments (instead of perhaps interviewing the users directly) was made in accordance with two criteria based on theoretical postulates: first, as noted by Chesterman ("Bridge Concepts in Translation Sociology"), translation users produce cognitive reactions as soon as they come into contact with the translated content, potentially generating a public feedback that the author calls response. Hence, we found pertinent to collect the users' genuine comments, resulting from their reactions upon being exposed to the dubbed game. Secondly, as pointed out by O'Hagan and Mangiron, critical game reviews, blogs, and fan-made message boards offer a rich collection of data for researchers.

The analysis of gaming blogs, message boards, and channels provided several comments made by gamers expressing their opinions about the PT-BR version of Uncharted 3 , addressing matters of dubbing, translation, quality of other dubbed versions, and the alleged superiority of the material originally produced in English. The publication dates of the collected 
posts range from 2011, when the dubbed trailer of the game was first released, to 2016, with the comments on YouTube's gameplay recordings that addressed more specific aspects of the translation of the game.

The second stage involved recording the gameplay with the aim of identifying norms that may have governed the official translation of the game's content, and would therefore be considered professional norms. Seeking to encompass as many game-composing features as possible, such as video, graphical animation, voiceovers, audio, text, and interactivity (Coelho and da Silva), we used the built-in recording functionality of the PlayStation 4 console to record the gameplay in high definition. This mechanism starts automatically as soon as the game is launched, or it can be activated manually by pressing a button in the controller at the desired starting point. The resulting file is auto-saved after fifteen minutes of recording, or it can be saved and shared manually using the same button mentioned above. The analysis of the gameplay recorded in Uncharted 3 was performed after processing the video files on the ELAN software, version 4.9.3 (The Language Arquive). The gameplay videos were segmented, transcribed, and contextualized using the features of the program. We collected 2,203 text lines throughout 9 hours and 22 minutes of gameplay, including transcribed lines from the PT-BR dubbing, the original voiceover in English shown in the closed caption subtitles, and the appropriate contextualization of each dialogue. These results were exported as a text table and as subtitle files so that they could be opened and analyzed with the gameplay videos. Figure 1 shows an example of ELAN's interface during the processing of one of the gameplay files.

Figure 1 - Example of ELAN's interface during the processing of the annotations

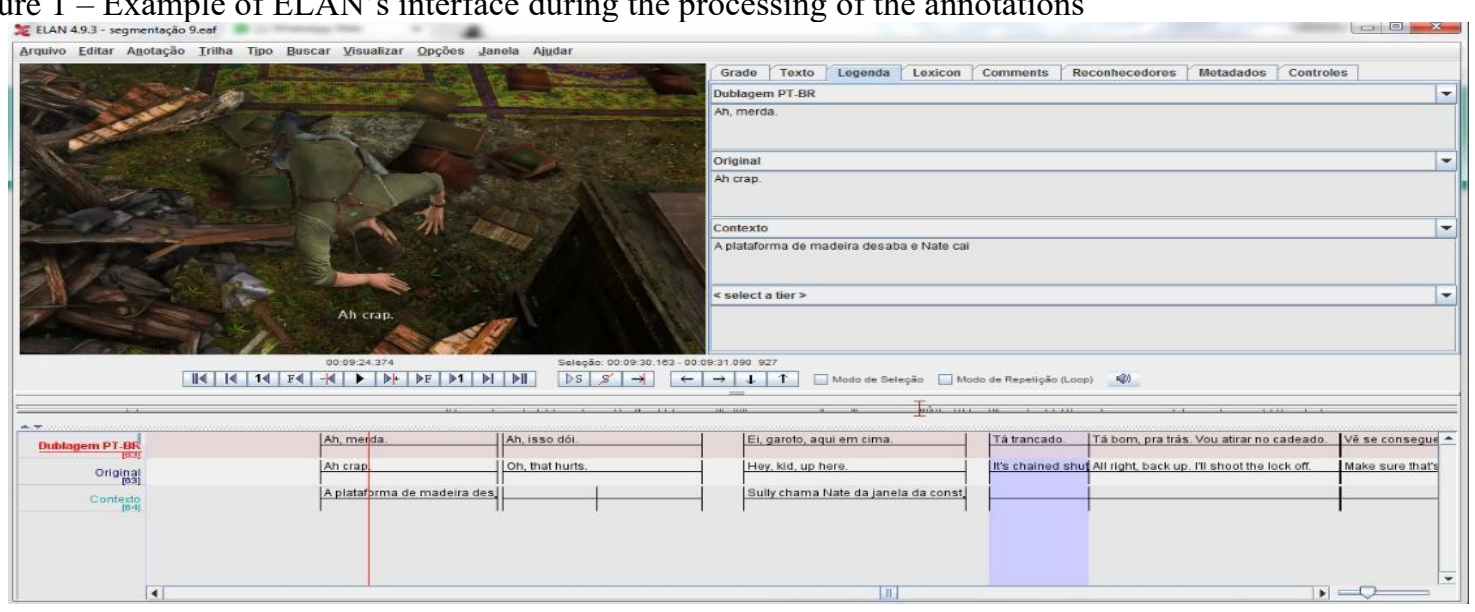

Source: screenshot of ELAN.

The chosen object of study, the game Uncharted 3: Drake's Deception, is the third game in the Uncharted action adventure franchise, preceded by Uncharted: Drake's Fortune, released in 
2007, and Uncharted 2: Among Thieves, released in 2009. The game, developed by Naughty Dog and published by Sony Computer Entertainment, was released in 2011 as a PS4 exclusive. It was the first game of the saga to have a fully localized version in Brazilian Portuguese, i.e., the first one to offer subtitles and dubbing in this language. The plot of the sequel continues the story of Nathan Drake, the treasure hunter, who now goes on a journey through the heart of the Arabian desert in search of the mythic "Atlantis of the Sands". In Brazil, the game was rated 14 (not recommended for minors under fourteen) according to ClassInd, the content rating system developed by the Brazilian Ministry of Justice (Ministério da Justiça), for containing violence and coarse language. In 2015, the game was remastered and relaunched, along with the first two games of the franchise, for the new generation of consoles, i.e. the PlayStation 4. The bundle received the title of Uncharted: The Nathan Drake Collection, and, in this edition, the first two games were also dubbed in Brazilian Portuguese.

The choice of this game as the object of this study was mainly motivated by the broad repercussion of its dubbed version, which caused controversy among users and therefore offered a good source of material for academic analysis. The game also has a linear plot, which makes it easier to analyze the collected data in a more objective and focused way.

\section{Results}

\subsection{Expectancy norms in translated games}

Chesterman ("Bridge Concepts in Translation Sociology") explains that translations generate effects on their users, causing what he names reaction, response, and repercussion. The author defines reaction as the effects of the text (i.e. the effects of the translations per se) in the cognitive spectrum (i.e. the mental and emotional reactions of the users). In a collective level, the reactions from translation users help create a shared concept of translation and translator. Responses are the observable behavior actions originated from the users' reaction, namely any type of feedback regarding a certain translation. Repercussion, in turn, is the effect of translation in a cultural level, comprising changes or events caused by the responses that a certain translation evoked (e.g. the canonization of a literary work, changes in the evolution of the target language, changes in norms and practices, etc.).

Game translation operates under a complex variety of factors: on the one hand, there is the requirement to fit in the technical and cultural specifications of each target territory; on the other hand, there is the pressure to maintain the same potential experience of the original game. Furthermore, there are also hardcore fans with vast knowledge of games and a few franchises 
in particular. All of these factors contribute to the emergence of expectancy norms, which, in turn, affect the professional norms of the field ${ }^{4}$ (O’Hagan and Mangiron).

The matter of good and bad quality of translations has entered the gaming community's consciousness and become a fervent topic of discussion among them (J. Newman). There is some controversy as to how different user groups perceive the quality of translated games, seeing as, for example, some more dedicated users may see fully adapted games as inappropriate for depriving them of the original tone of the game, whereas other players may get annoyed at even the slightest trace of "foreignness" in a translated game (O'Hagan and Mangiron).

As mentioned in the previous section, the comments were collected from the Portuguese website Eurogamer.pt and from four YouTube gaming channels that posted the full gameplay of Uncharted 3 dubbed in PT-BR.

In total, we collected 125 comments, and after gathering them, we sought to identify the most recurring arguments mentioned by the players, subsequently classifying them according to the perspective under which the gamers addressed the translation and dubbing of the game.

180 After ruling out posts that were too general, comments that were more focused on the plot, and those that compared Uncharted 3 to games of other franchises, we analyzed 56 comments that specifically referenced the translation of the game.

Considering the main perspectives adopted by the gamers when expressing their opinions, we created five categories: 1) overestimation of the original (hereinafter $\mathrm{OO}$ ), 2) Eurocentric perceptions (hereinafter EP), 3) perceptions of the linguistic choices in the translation (hereinafter PLCT), 4) perceptions of subtitling vs. dubbing (hereinafter PSxD), and 5) perceptions of the responsibility for the service (hereinafter PRS). The categories were identified according to what was genuinely discussed by the gamers.

Figure 2 shows the incidence of the comments from the users according to the established categories, organized from the most frequent category to the least frequent one. 
Figure 2 - Graph showing the statistics of incidence of comments in each category, namely OO (overestimation of the original), PLCT (perceptions of the linguistic choices in the translation), EP (Eurocentric perceptions), PSxD (perceptions of subtitling vs. dubbing), and PRS (perceptions of the responsibility for the service)

\section{INCIDENCE OF COMMENTS}

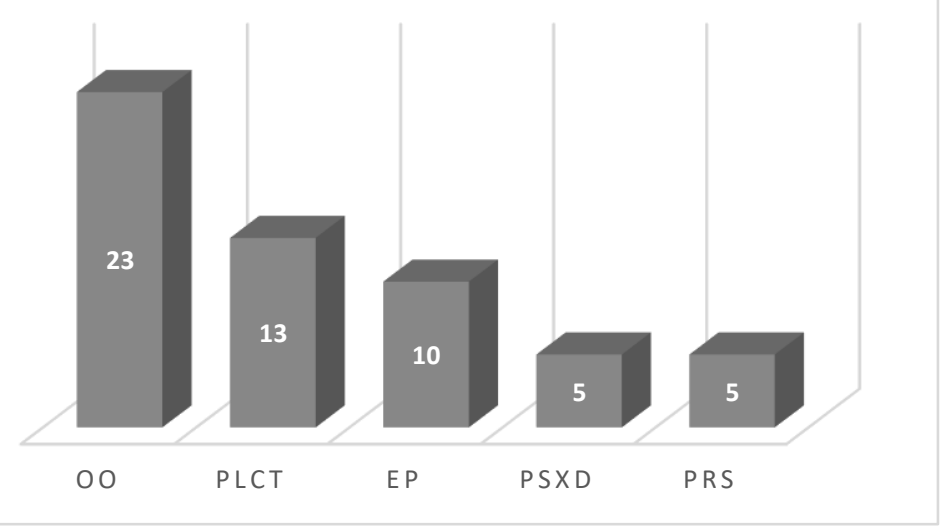

Source: the authors.

The most frequent comments were those in the OO category, with 23 instances, followed by PLCT with 13 comments, EP with 10 posts, and, finally, PSxD and PRS with 5 instances each. Due to space limitations, only a few of these comments will be discussed.

In the following tables, each line represents a comment made by a different player. The translations of the comments aimed to be as close as possible to the originals in both content and style.

Table 1 - Gamers' comments in the OO category

\begin{tabular}{|l|c|}
\hline \multicolumn{1}{|c|}{ Comments } & Publication Date \\
\hline $\begin{array}{l}\text { Honestly, I thought this dubbing was weird as f***, could you please set the audio in } \\
\text { English and the subtitles in Portuguese, Edu? }\end{array}$ & 2015 \\
\hline $\begin{array}{l}\text { Dude, what an awful dubbing. Edu, if possible, change the language settings to English } \\
\text { with subtitles in PT-BR. Thanks. }\end{array}$ & 2015 \\
\hline $\begin{array}{l}\text { The game may be new, but the dubbing sure is bad. Edu, put the voices in English with } \\
\text { subtitles in PT-BR, please. }\end{array}$ & 2015 \\
\hline Damn, Edu, it's better to leave it in English 'cause this dubbing is crap. & 2015 \\
\hline Put the game in English. The dubbing is so lame. & 2015 \\
\hline $\begin{array}{l}\text { This is one of the best games I've ever played, but this dubbing in Portuguese is awful, } \\
\text { the original in English is SO MUCH better! }\end{array}$ & 2015 \\
\hline
\end{tabular}

Source: BRKsEDU.

The comments with the highest rate were the ones that evidenced the overestimation of the original version as opposed to the translation. As shown in Table 1, the comments reveal that the users, in the words of Venuti, see the original as an act of self-expression in a one-of-a-kind 
text, whereas the translation is perceived as a derivation that imitates the original, causing fear of inauthenticity and distortion. In spite of this, for the game to evoke a similar potential of gameplay experience in the players of a country that was not the one where the game was originally conceived, the aim of the translation would be, as a professional norm, to be adapted for the linguistic features of the target locale. In this context, it is also possible to say that the expectancy norms do not match the premise of the professional norms of game translation. According to Venuti, the veneration of foreign languages and literatures, which is irrational in its radicalism, makes it unlikely that the public will see any translation as acceptable. Nevertheless, since game translation, both in Brazil and elsewhere, has yet to achieve the ideal postulates of professional and training practices for translators and localizers (Bernal-Merino), we can infer that translated games are still unable to provide the same potential of experience of the original game for having its interactivity altered or hindered.

The second category in the order of incidence was the PLCT (perceptions of the linguistic choices of the translation), which comprises comments about the translation task itself and shows specific situations in which the gamers noticed alleged errors or mistranslations.

182 Several users commented on the linguistic choice (illustrated in the quote that introduces this paper) of the term "barbada", posting their opinions on the gameplay video published on the YouTube channel BRKsEDU. A few users shared the same opinion, but some of them disagreed.

The players' perception demonstrates what Robinson argues about each translation user having a different expectation that is determined by their situational needs, even though they may believe their opinion are related to the nature of translation itself. Some players, perhaps for living in a region where the expression "barbada" is widely used, felt that the translation met their expectations, while others, who probably reside in other regions of the country, felt unease upon hearing the expression, thus not having their expectations fulfilled. 
Table 2 - Gamers' comments in the PLCT category

\begin{tabular}{|l|c|}
\hline \multicolumn{1}{|c|}{ Comments } & Publication Date \\
\hline $\begin{array}{l}\text { Gaúcha6 dubbing? It's pretty funny. But I think the dialogue was missing a little bit of } \\
\text { intelligibility. }\end{array}$ & 2015 \\
\hline $\begin{array}{l}\text { They translated "Very, very" as "muito, muito" and "I got it" as "consegui", out of context. } \\
\text { Hahaha, it's funny. }\end{array}$ & 2015 \\
\hline $\begin{array}{l}\text { I think dubbing is really unnecessary for those who speak English, but I think Uncharted } \\
4 \text { will have the same dubbing actors who worked in Uncharted 3, but the dubbing will be } \\
\text { better, since The Last of Us was pretty awesome. }\end{array}$ & 2015 \\
\hline $\begin{array}{l}\text { Dubbing nowadays is certainly better. Now imagine if they hire a celebrity to do the } \\
\text { dubbing :/ }\end{array}$ & 2015 \\
\hline $\begin{array}{l}\text { Without the translation, the character says puta que pariu?, and when they translate it, he } \\
\text { says "barbada". }\end{array}$ & 2015 \\
\hline Here in the South we say "Barbada", Edu hahaha & 2015 \\
\hline Awesome game!! "barbada", right "gauchada"? & 2015 \\
\hline Edu, here in the South we say barbada lol & 2015 \\
\hline Barbada? I agree, Edu, why use these words? Lol & 2015 \\
\hline
\end{tabular}

Source: BRKsEDU.

The category with the third highest rate was the one that included comments revealing the Eurocentric perception held by some Brazilian players. The comments about the trailer of the game, specifically, were posted on the Portuguese website Eurogamer.pt, where an article was published in 2011 about a then-recent controversy involving the release of the trailer for

Uncharted 3: Drake's Deception dubbed in Brazilian Portuguese. The controversy involved the rejection of a dubbing service proposition made by a Brazilian specialized company. Although the party responsible for the decision was never revealed (whether it was the developer, Naughty Dog, or the publisher, Sony Brasil), the fact remained that the service was later commissioned to a Miami-based company, and when comparing the trailers with the two different versions, Brazilian gamers felt unsatisfied with the service that was ultimately chosen and used in the game. 
Table 3: Gamers' comments in the EP category

\begin{tabular}{|c|c|}
\hline Comments & Publication Date \\
\hline $\begin{array}{l}\text { I think the PT-PT dubbing actor is much more charismatic, "quando estais a matar } \\
\text { parvalhões" } .: \mathrm{P}\end{array}$ & 2015 \\
\hline One of the few times where a Portuguese dubbing is better & NA \\
\hline Parvalhões ${ }^{10}$ ? lol I think they meant vagabundo ${ }^{11}$ lol. & NA \\
\hline $\begin{array}{l}\text { Hahaha, I think that, for now, PT-PT dubbing is indeed better than ours, but this will } \\
\text { change soon (either that or we'll get used to it). :) }\end{array}$ & NA \\
\hline I don't really know what it means, but Drake says "parvalhão" all the time hahahaha. & NA \\
\hline Dude, parvalhão could mean stupid, fool, idiot in this context. & NA \\
\hline I prefer the dubbing in Portuguese from Portugal $: \backslash$ & 2015 \\
\hline I found the PT-PT dubbing to be better... & 2015 \\
\hline In Portuguese from Portugal is much better. & 2015 \\
\hline $\begin{array}{l}\text { Edu, can't you set the dubbing in PT-PT? I find the dubbing to be a lot cooler and I think } \\
\text { everyone will feel the same. }\end{array}$ & 2015 \\
\hline The PT-BR dubbing is pretty bad, PT-PT in Uncharted 2 was much better... & 2015 \\
\hline Damn, what a shitty dubbing, I prefer the one from Portugal lol. & 2016 \\
\hline Portuguese from Portugal is way better. & 2014 and 2015 \\
\hline Hahahahahahhahahahahahahaha no... & 2014 and 2015 \\
\hline This is a matter of opinion, I agree with Marcelo, Uncharted in PT-PT is awesome. & 2014 and 2015 \\
\hline $\begin{array}{l}\text { I agree too, Uncharted } 3 \text { in PT-PT is excellent, the Portuguese dubbing actor that plays } \\
\text { Nate is my hero } \mathrm{xD} \text {. }\end{array}$ & 2014 and 2015 \\
\hline $\begin{array}{l}\text { It's not fair, better to leave it in the American version or import the Portuguese one, which } \\
\text { has a great dubbing (even though it sounds weird to us). Still better than the one made in } \\
\text { MIAMI. }\end{array}$ & 2011 \\
\hline
\end{tabular}

Source: Eurogamer.pt; BRKsEDU.

Table 3 shows examples of the preference of some gamers for the version in European Portuguese. Even though one might instinctively make the assumption that the European version is simply better, most of these gamers do not present clear arguments to justify their preference. In game localization theory, each translation of a video game is aimed at a different locale and is therefore open to customization. Despite the fact that, technically, both Portugal and Brazil speak Portuguese, each country uses a distinct and culturally-imbued variation of the language. This contradictory point of view on the part of the users - i.e., preferring something that feels unnatural to them - may have its origins in a Eurocentric perspective that becomes evident in expressed opinions.

Even though the colonial dominance is practically over at this point, a large portion of the world still remains under the aegis of a sort of neocolonialism, i.e., a type of abstract and indirect control (Shohat and Stam). Colonized countries tend to parody and mimic the practices of the elite, and despite the existence of a hybridization among countries, those that are seen as part of the 'first world' are usually seen as a cultural transmitter, while the others are reduced 
to the status of receivers (Shohat and Stam). This kind of point of view can be seen in some of the comments made by Brazilian gamers, but it is possible to infer where they are coming from when making these statements.

The first games of the Uncharted franchise were retailed in Brazil with the option to set the audio to dubbed voiceovers in European Portuguese, forcing the non-English-speaking players to choose the option that they felt was easier to understand. Thus, one can assume that, from the release of the first game, back in 2007, to the launch of the third one, in 2011, an expectancy norm related to the European dubbing and its alleged quality emerged among the Brazilian players, and these expectations do not seem to have been met by the Brazilian dubbing. Still, it could be considered odd for a player to prefer a second-best option and continue to see it as superior, even when faced with the availability of a product made in their own language (variation). Such a case can be seen in one of the comments mentioned above, in which the player says that "Hahaha I think that, for now, PT-PT dubbing is indeed better than ours, but this will change soon (either that or we'll get used to it). :)".

The category with the fourth highest incidence, with five comments in total, was the one referring to the comparison between dubbing and subtitling. According to O'Hagan and Mangiron, games are becoming increasingly similar to movies, something that is evidenced in the widely-used term "cinematic games" (R. Newman). One of the current trends is to produce these games with a confluence between cut-scenes (pre-rendered video sequences) and interactive gameplay, making them continuously integrated through the use of high-definition graphics and voiceovers performed by professional actors. The cinematic features used in these media have led to subtitling and dubbing of dialogues, even though the norms that govern these practices differ from those adopted in Audiovisual Translation.

Subtitling and dubbing each have its own specificities (Koolstra, Peeters, and Spinhof). For instance, dubbing requires that the text be adapted so that it matches speech time and lip sync, while subtitling usually condenses the content within the 64-character limit (32 characters per line, including spaces), which can remain on-screen for up to six seconds. In games, however, these criteria and distinctions between modalities are not usually employed, at least not entirely, especially when it comes to subtitling (Bernal-Merino; Teixeira). Games usually display dialogical texts on screen in a similar fashion to what is seen in movies, but instead of following the standard system, each game seems to use diverging criteria depending on what is better suited to the interface, sometimes using subtitles with over 100 characters per line, amounting to up to five lines on screen at a time. In addition, Bernal-Merino emphasizes that 
intralinguistic subtitles are actually transcriptions of the audio of the game (narration and dialogue). In the more specific case of fully-localized games in Brazilian Portuguese, i.e., games with subtitles and voiceovers in this language, the subtitles tend to be more similar to the audio, a phenomenon that Souza ("Video Game Localization") addressed in his investigation; he found that the subtitles did not present any changes when compared to the in-game dialogue in the same language.

Even though Bernal-Merino, who is also supported by a study in the Brazilian context (see Teixeira), argue in favor of creating parameters specific to game subtitling and dubbing i.e., establishing professional norms that can govern these practices - the comments of the players are indicative of their expectation to find equivalent subtitles and dubbing. When faced with discrepancies between what they heard and what they read, these gamers felt uncomfortable and discontent.

Table 4 - Gamers' comments in the PSxD category

\begin{tabular}{|l|c|}
\hline \multicolumn{1}{|c|}{ Comment } & Publication Date \\
\hline $\begin{array}{l}\text { Fuck. What a shitty dubbing/subtitling. They don't match. The characters say things that } \\
\text { are not written... }\end{array}$ & 2015 \\
\hline The subtitles are very different from the dubbing!! ? & 2015 \\
\hline $\begin{array}{l}\text { The saga is amazing, no doubt, but it's weird reading subtitles that are totally different } \\
\text { from the dubbing... }\end{array}$ & 2015 \\
\hline $\begin{array}{l}\text { "Chispa daqui"'2??? Didn't he say "sai daqui" "??? damn, these subtitles. } \\
\text { subtitles. }\end{array}$ & 2015 \\
\hline $\begin{array}{l}\text { The game is awesome, but I couldn't understand the meaning of it and it's annoying to } \\
\text { have the subtitles saying one thing and the dubbing actors saying another, it's bad. Edu, } \\
\text { see what you can do about that. It's not disruptive, but } \\
\text { it's annoying. Thanks! }\end{array}$ & 2015 \\
\hline
\end{tabular}

Source: BRKsEDU.

Finally, the last category we established, in which there were also five comments, was the one about the users' perceptions of the responsibility for the service. This kind of comments point to the confusion many gamers have in regard to the party that is actually in charge of translating a game. Some discussions, like in Table 5, illustrate how distinct the perspective of each user can be when it comes to the responsibility over the translation of a game and its quality (or lack thereof). 
Table 5 - Gamers' comments in the EP category

\begin{tabular}{|l|c|}
\hline \multicolumn{1}{|c|}{ Comment } & Publication Date \\
\hline $\begin{array}{l}\text { The game is amazing and the graphics are excellent, I just think the developers messed up } \\
\text { with the PT-BR dubbing, other than that, the game is awesome. }\end{array}$ & 2015 \\
\hline $\begin{array}{l}\text { Where is the emotion on the characters' faces? The dubbing does not make it look like they } \\
\text { are in a bad situation. Damn it, Naughty Dog. }\end{array}$ & 2015 \\
\hline
\end{tabular}

Source: BRKsEDU.

For instance, some gamers believe that the developer is to blame when a translation lacks quality. Even though many of these companies use the in-house model of localization, i.e., an internal team that deals with all translation commissions, this is more common in locales where virtually (nearly) all games are localized. A good example of this is the E-FIGS languages, i.e., English, French, Italian, German, and Spanish, to which the translation of content has long been considered a standard procedure in most game developers and publishers (Chandler and Deming). However, this is not the case in Brazil, where the market of game translation is still fairly new, and where outsourcing (commissioning translation services to third-party companies) prevails as the most widely used model of practice, which means that the developer has little or nothing to do with the final translation of the game.

Another relatively mistaken assumption is that the company in charge of dubbing the game is "to blame" for the bad quality of a translation. Even though the aim of this research was not to pass judgement on the quality of the dubbing of the game under analysis, this kind of situation is not unprecedented in the literature. For example, Koolstra, Peeters, and Spinhof state that dubbing and subtitling services are often criticized, even when the quality is actually more tied to the translation procedures. More specifically speaking, O'Hagan and Mangiron note that in game dubbing, users often complain about issues such as bad acting (e.g., lack of emotion in the voiceover), and no sync between audio and image, essentially placing the blame on the dubbing team. However, as emphasized by the authors, this kind of issue also occurs due to task procedures imposed to the translators, such as having to translate all lines from a character in separate, having no indication of whom they are talking to or in what point of the game these lines will take place. The files that the translators and dubbing actors receive do not usually come with information about context or tone, further increasing the risk of producing an inappropriate translation and dubbing (Bernal-Merino).

In the case of Uncharted 3: Drake's Deception, the exact authorship of the translated version in Brazilian Portuguese is obscure at best. In the credits of the game, even in its Brazilian version, there is no information about the team in charge of the PT-BR translation 
(although other translated versions are featured in the credits, such as the one from Southc Korea). Thus, it is difficult to have an accurate perception of the source of the service, since the game industry is still sensitive about disclosing information (O'Hagan and Mangiron), making it hard for outsiders (users, researchers, or others) to get access to certain data regarding the translation.

\subsection{Professional norms in translated games}

According to Chesterman (Memes of Translation), professional norms are procedural in nature and govern the translator's work behavior. They are conditional to expectancy norms, since any procedural norms are determined by the nature of the final product and what is expected of it. Professional norms are generally imposed by other translation behaviors that are considered ideal in specific cultural and linguistic dimensions.

In game translation, there is usually a gap between internal and external knowledge. On one side of the spectrum are the professional translators, who may not be knowledgeable in gaming culture; on the other side are the hardcore fans with deep knowledge of the product, but most likely lacking the notions related to the professional norms (Chesterman, Memes of Translation) that govern game translation. O'Hagan and Mangiron propose a collaborative translation model with a process that takes advantage of the insight of these users, having the contact between expectancy and professional norms enable both to be remodeled into a new set of norms resulting from the convergence between internal and external knowledge (Pym). However, the authors themselves recognize that this is a challenging proposition, and that there are several obstacles for putting it in practice. Therefore, when Wood, Krauss and Raveto argue that game localization and translation professionals should above all be gamers themselves and have knowledge of the industry and the terminology in the field, she provides an intermediate and more viable option for dealing with the issue.

As such, this section focuses on exemplifying some issues in the translation of the game, which the users, unaware of the professional norms that seem to govern this type of translation, were unable to notice or did not react to in a way that generated feedback (i.e., a response) (Chesterman, Memes of Translation).

In game translation, the translator rarely has the opportunity to play or even see the game on which they are working, and they seldomly have access to context information. This explains why game translation is frequently described as "blind localization" (Dietz). Under these circumstances, the translator must rely on their intuition and knowledge of games and 
gaming culture, making educated guesses about the context and providing flexible translations that work in different settings (O'Hagan; Mangiron). When said knowledge is limited or superficial, problems may arise in the translation task, as will be exemplified below.

Out-of-context translation is more common in outsourcing models, in which the developer or publisher commissions the service to a third-party localization company. This company is then in charge of selecting translators, integrating the features of the game, creating the dubbing script (and commissioning the service, usually to another third-party company), and sometimes performing the linguistic quality assurance (LQA).

Despite the fact that game developers have become increasingly aware of the need to provide context for the translation process, it is still common for translators to receive scripts and Excel files with detached text segments and no information about their context. This makes the job of the translator extremely more difficult, potentially causing a high number of errors and inappropriate translations in the final product. This potentiality for mistakes is even higher when several translators are involved in the project and are not able to consult with one another, or even when the content is sent in a non-chronological order in relation to the plot of the game. The issue of lack of context can also affect the voiceover actors working in the dubbing of the game, for they base themselves in context and tone when adjusting their performance.

In search of exemplifying potential issues in the professional norms that governed the translation of the game herein studied, we collected samples based on two criteria: in addition to being examples of mistranslation or inaccuracies, we selected issues that could be easily detected with no prior knowledge of the original material. In other words, we chose situations that could be noticed by gamers playing the dubbed version with no access to the source text (and who might not be proficient in the source language).

We selected the samples using the gameplay videos played in tandem with the annotations made in ELAN, which had been previously saved as subtitle files. Figures 3 to 6 are examples of situations where there might have been a lack of context that led to a mistranslation.

Figure 3 shows Sully and Nate escaping a burning building, leaving the crumbling construction in their wake. Upon reaching safety, Nate asks if Sully is okay, to which he answers, in the original, that he is "just swell." The PT-BR translation used was "Só inchado", which has a very non-ambiguous meaning of "Just swollen.", as in having a swelling somewhere in his body. According to the Cambridge Dictionaries Online, the word "swell" as an adverb, as it was used in the game, is an old-fashioned informal term that means "very well". 
Even though, in this context, the translation can be easily considered inappropriate, a lack of overall context and more information about each character (e.g., the fact that Sully is an older man, and would therefore be more likely to use such old-fashioned expressions) could have contributed to this case of mistranslation.

Figure 3-Gameplay analysis - Chapter 7: Stay in the Light

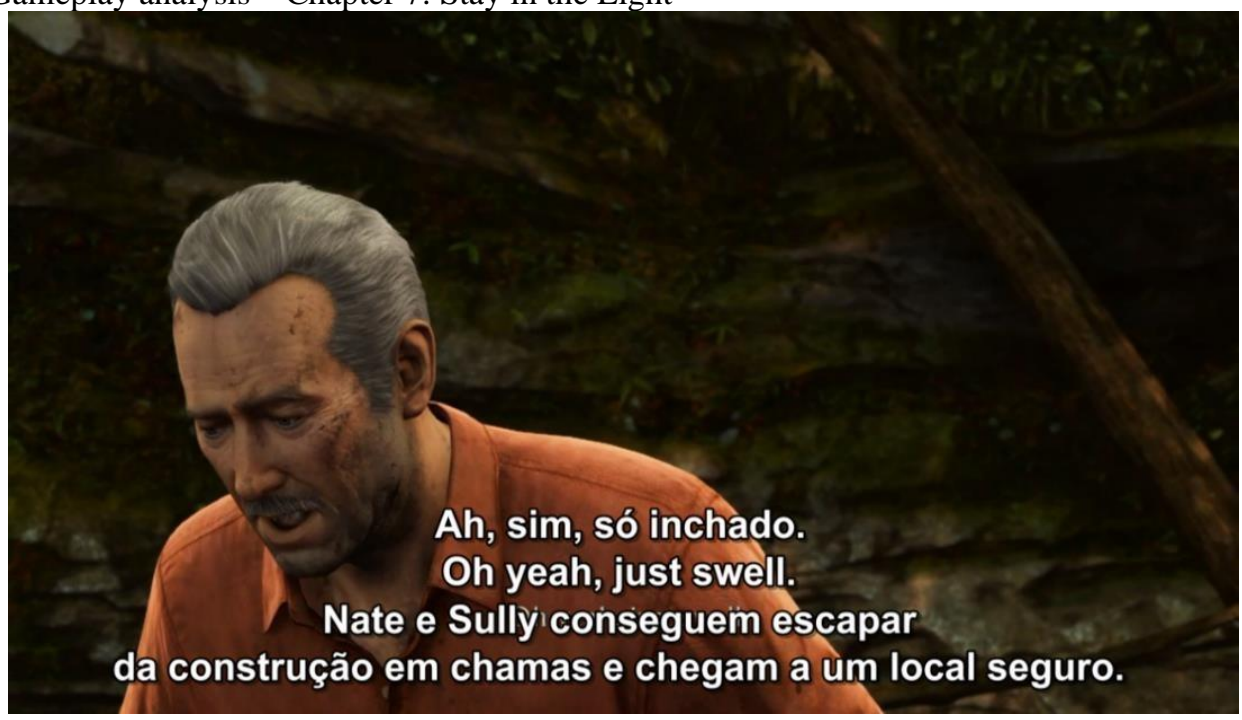

Source: the authors.

Figure 4 shows Nate, Sully, and Elena entering a supposedly safe building after having escaped from the villain's henchmen. Since the characters had to leave their guns outside the city due to the local laws, they were now being hopelessly pursued by thugs. Then, Elena suggests that Sully should seek a "rug merchant" (who is in fact a weapons dealer) they had just passed, so that they would not be caught unprepared while moving forward. Sully returns with two shotguns, which are easily recognized by any gamer who has already played a shooter ${ }^{14}$ before. In the original, Elena asks "Shotguns?", but the translation uses the term 'Rifles', which is an English loanword for an entirely different type of weapon. The terminological equivalence of shotgun, in Brazilian Portuguese, would be 'escopeta' or 'espingarda', which are long-barreled or sawed-off smoothbore weapons that shoot small spherical pellets or slugs, and are more appropriate for close-range combat (Brunogeoufc). In contrast, rifles, also called 'fuzis' in Brazilian Portuguese, are long rifled weapons that come in different versions, such as repeating, semi-automatic, or automatic rifles (“Armas de Fogo"). They are long-range weapons that shoot rifle projectiles with a high level of precision (Brunogeoufc). Even though a quick research on weaponry would show the difference between these two gun types, the absence of context or even of an in-game screenshot showing the actual objects in the character's hand could have 
contributed to this lack of attention to an arguably small detail. Furthermore, this situation may have been influenced by a limited external knowledge on the part of the translator, which is to say that the professional may not have been aware of the important aspect of gaming culture that involves weapons and their names, classes, and design.

Figure 4 - Gameplay analysis - Chapter 10: Historical Research

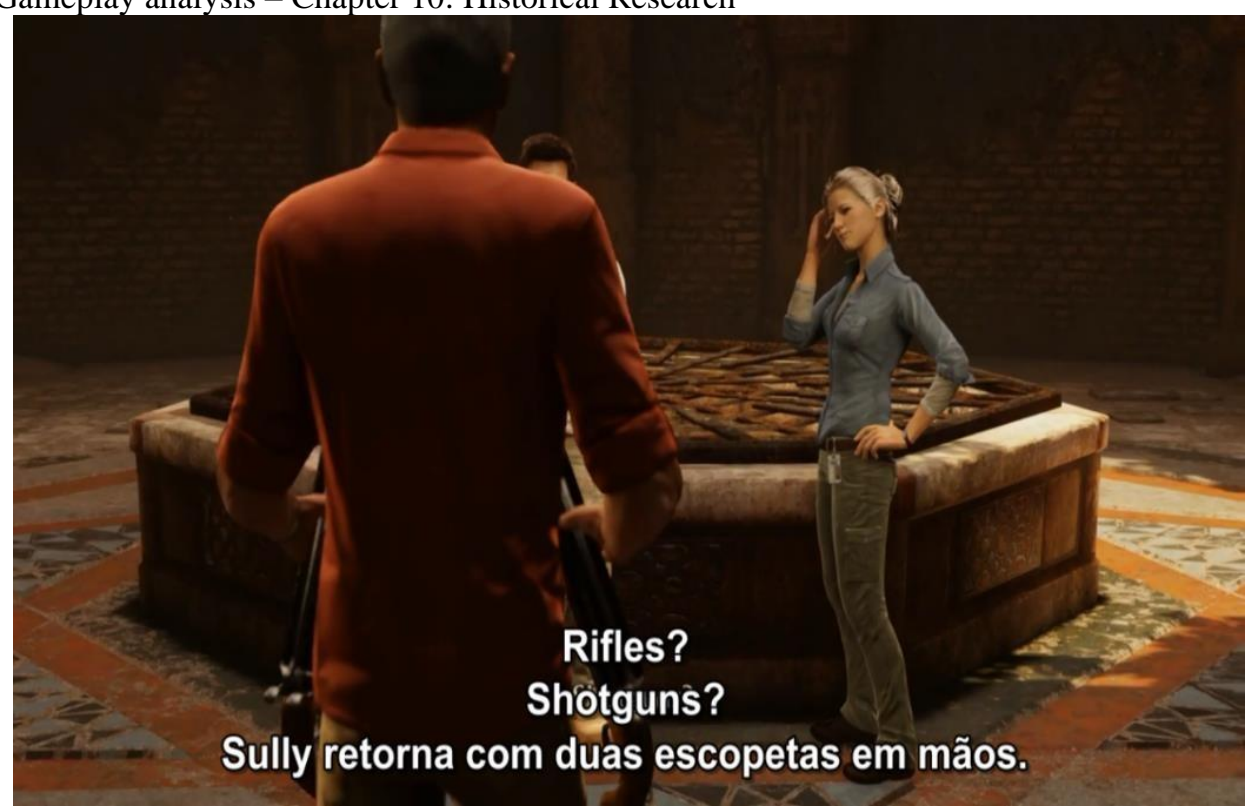

Source: the authors.

Figure 5 shows the most evident example of (potential) lack of context in the translation of this game. Nate and Sully are being led to the Atlantis of the Sands by their ally Salim and his tribe. They come across a sand storm, making Nate and Sully get separated and lost from the rest of the group. In the Uncharted franchise, Nate is often running from enemies, and a frequent objective of these games is to escape and lose these antagonists. According to the Cambridge Dictionaries Online, the verb 'despistar' means 'to disorient', 'to put/throw (someone) off the scent'. In this case, the use of this term did not convey the correct idea that the characters got lost from their allies, instead giving the sense that they had thrown their enemies off their scent. Such a mistranslation can be easily attributed to an out-of-context source text, but there is also the possibility of the entire translation process having been guided by translation memory systems and their functionality of auto-completing full or fuzzy matches of previously translated segments. This is possible in this conjuncture, since many other situations had a similar, if not identical, sentence where the meaning was indeed the one of throwing someone off the characters' scent. 
Figure 5 - Gameplay analysis - Chapter 20: Caravan.

\section{Despistamos eles! \\ We must? \\ Nate $\Theta$ Sully perdem Salim e seus \\ allados de vista em melo à tempestade de areia.}

Source: the authors.

Figure 6 shows the final part of the game, in which Nate and Sully find the Atlantis of the Sands and discover its gates protected by a locking mechanism. While figuring out how to open the

passage, Sully mentions that he managed to snatch back the notebook that Marlowe, the villain, had stolen from Nate. When Nate answers by saying "Still got it", he uses this idiom to express that his friend still has a way with sneaky thievery, even after all those years, referencing a whole plotline previously shown in the earlier games of the franchise. However, the translation conveys a much more general and mistaken meaning that Nate still has his notebook, producing a nonsensical idea in regard to the plot, since Nate had lost the object and did not have it with him at that point. When faced with a sentence such as "Still got it" and missing any other information about its context or a broader knowledge of the backstory of the franchise, it would not be hard to make the mistake present in the dubbed version, seeing as the phrase can have this meaning when interpreted in the literal sense. 
Figure 6 - Gameplay analysis - Chapter 20: Caravan (2)

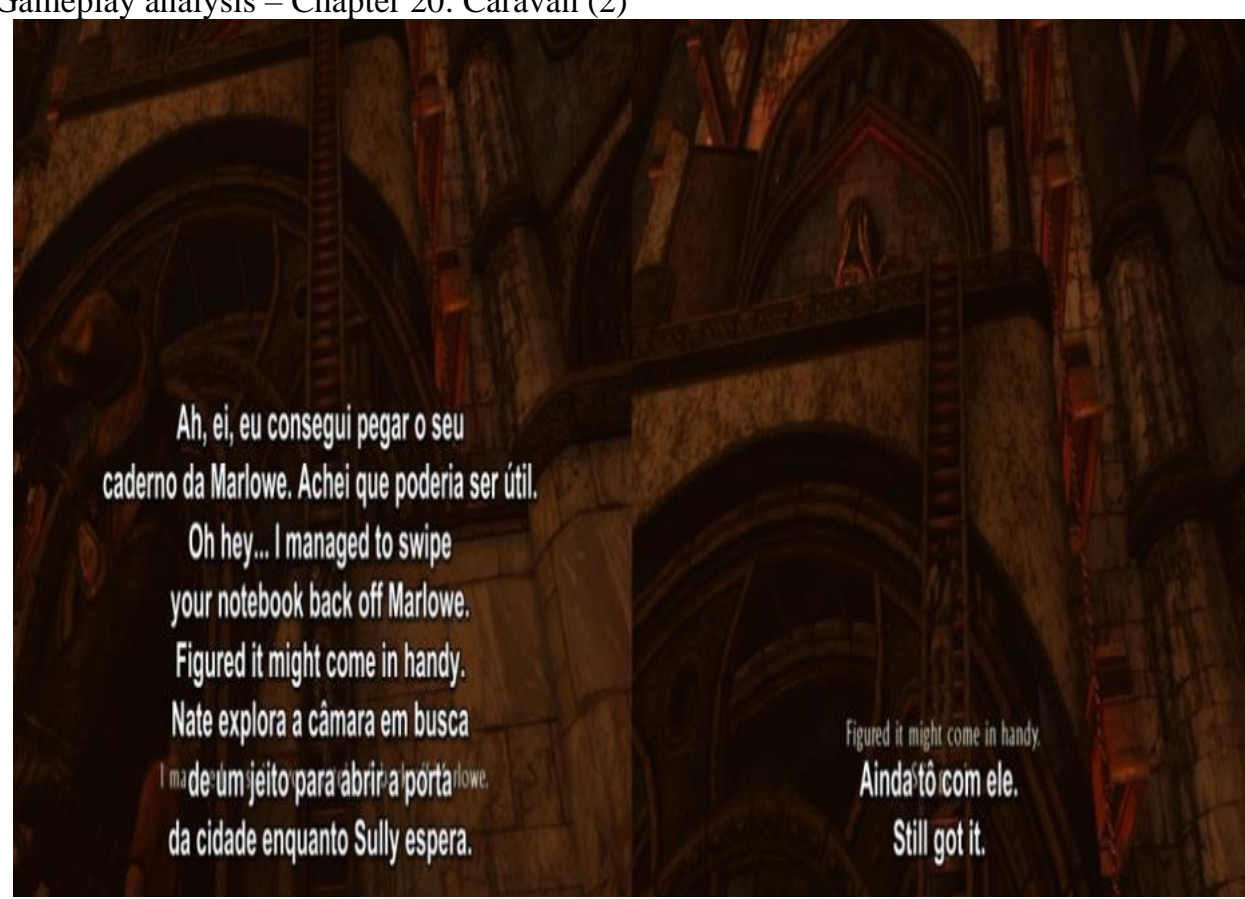

Source: the authors.

Even though professional norms are highly influenced by expectancy norms, O'Hagan and Mangiron mention a crucial point about this relationship, and a potential reason behind the conflict between them: users are usually unaware of all the restrictions imposed to game translators in their work - such as the fact that some projects must be completed without any context - leading these players to create expectations that do not match the reality of the professional practice.

\section{Final Remarks}

This study aimed to analyze the point of view of users of translated games, an approach which O'Hagan and Mangiron point out as still unexplored by academic research in this field. To that end, we chose to analyze the reception of the game Uncharted 3: Drake's Deception, using the comments made by its players about the dubbed version in Brazilian Portuguese. After collecting the comments from websites and YouTube channels so that the users' response could be better captured, we divided the material into five categories created according to the perspectives of the players, namely overestimation of the original, perceptions of the linguistic choices of the translation, Eurocentric perceptions, perceptions of subtitling vs. dubbing, and perceptions of the responsibility for the service. 
The gameplay was recorded and analyzed using the PS4 console and the ELAN software (Coelho and Da Silva). The analysis of the comments and gameplay was based mainly on the expectancy and professional norms proposed by Chesterman (Memes of Translation). We sought to draw a parallel between both sides of the spectrum: the point of view of the gamers and their expectations, and the professional norms of game translation.

Regarding the expectancy norms, we observed that, as argued by Robinson, the users of a translation - the gamers, in this case - have situational and idiosyncratic expectations, and believe that their point of view about translation is not only shared by all other users, but is also equivalent to the very concept of translation and its ideals. Another point that was evidenced after the data analysis was that the expectancy norms of Brazilian users of translated games were influenced by a few factors: on the one hand, their expectations were influenced by the residual Eurocentric perspective shared by many Brazilians, who see themselves as mere receptors of content (as opposed to the creators that they eventually became), and perceive the European Portuguese-language version of Uncharted 3 as rendering a superior and flawless translation. On the other hand, the translation scandals that affect other types of translation, 194 such as the matter of authorship (Venuti), are also present in game translation, highlighting an overestimation of the original in detriment of the often-demeaned translation. Even though Venuti also argues about the erasure of authorship as a result of over-domestication, adapting content to a target locale is the most basic premise of localization, thus justifying the levels of alteration usually employed in full-loc game versions.

Even though Chesterman argues that professional norms are influenced by the norms of expectancy, what became evident in the comments of the users was a relationship in the opposite direction, where the professional norms that govern game translation ended up instilling expectancy norms in the gamers. The matter of game subtitling and dubbing is a good example of this: the professional practice of these two modalities within game translation comprises the non-differentiation between them, leaving translated games with subtitles that are mere transcriptions of the game's audio and are often originated from the same script created for the dubbing. This practice - that has become standard over the years and is therefore a professional norm - has a clear influence on the expectations of the gamers, who demonstrate discomfort when they come across subtitles that were created separately from the dubbing, as observed in the opinions about the game herein analyzed.

As for the professional norms, this study used the gameplay analysis to converge theory and practice and obtain a better understanding of the relationship between them. The gameplay 
recording - that resulted in 2,203 text lines transcribed from the dialogue - was executed with the goal of detecting potential professional norms in the translation of the game. We observed that even though the gamers certainly have their expectancy norms, many issues associated with the professional norms go unnoticed by them. The biggest issue evidenced by our analysis was the scarce information about context that game translators usually receive. This professional norm has noticeable consequences in the final result of a translated game, running counter the expectations of quality shared by most gamers, even though these users do not mention such factors in their responses.

Therefore, what could be assumed from the results we obtained in this study is that many of the conflicting points between the users' expectations and the professional norms of game translation could be resolved mainly through a more open attitude from the industry in regard to their practices. This would give the players a chance to have a better understanding of how exactly the translation and localization process happens, and thus establish expectancy norms that are more in line with what is actually feasible in face of the existing restrictions. Another call for improvement would be to change the professional norms of game translation so that more context information is given to the translators in order to enable them to make translation choices that are more grounded and to minimize the errors caused by such deficiencies, ultimately making it easier for them to meet the users expectations of the users.

If these changes do not or cannot be implemented, a more viable solution for this matter would be having gamer translators (Ranyard and Wood) with knowledge of the product and the culture imbued in it, allowing them to avoid mistakes by making more educated guesses or finding solutions that work in different scenarios when faced with a material that has little or no context. Another possible solution is adopting a crowdsourcing translation model in such a way as to establish a dynamic relationship between translation, technology, the game localization industry, and translator training institutions.

Although this research aimed to shed light onto the proposed topics, there is still much to be addressed when it comes to a sociological point of view in game translation. For instance, due to the reasons previously mentioned, there still has not been an empirical and detailed investigation about professional norms. A research on this topic would be beneficial for translator training, as well as shedding light on the users' perspectives about the field. Furthermore, reception could be approached in questionnaires or interviews with subject groups, allowing more focused and expressive results, or in an investigation of the actual 
cognitive aspect involved in the gamers' opinion-forming process, which could provide a better understanding of the diverging expectancy norms among this group.

Finally, the title of this paper, besides aiming at an evident wordplay, references the still uncharted approach to the point of view of users of translated games in academic research.

\section{References}

“Armas de Fogo." Atirando, http://www.atirando.com.br/. Accessed on: 20 July 2016.

Bernal-Merino, Miguel Á. Translation and Localisation in Video Games: Making Entertainment Software Global. New York: Routledge, 2015. doi: https://doi.org/10.4324/9781315752334

BRKsEDU. Uncharted 3: Drake's Deception, https://www.youtube.com/user/BRKsEDU. Accessed on: 29 May 2016.

Brunogeoufc. Aprenda a Diferenciar os Tipos de Armas de Fogo, 2012, https://instrumentosdeguerra.wordpress.com/2012/09/17/aprenda-a-diferenciar-os-tipos-dearmas-de-fogo. Accessed on: 02 Mar. 2020.

Cambridge Dictionaries Online. Dicionário Inglês, $196 \mathrm{http} / / /$ dictionary.cambridge.org/pt/dicionario/ingles. Accessed on: 02 Mar. 2020.

Chandler, Heather Maxwell, and Stephanie O'Malley Deming. The Game Localization Handbook, 2nd edition, Jones \& Bartlett Learning, 2012.

Chesterman, Andrew. "Bridge Concepts in Translation Sociology." Constructing a Sociology of Translation, edited by Michaela Wolf and Alexandra Fukari, John Benjamins, 2007, pp. 171183. doi: https://doi.org/10.1075/btl.74.12che

Chesterman, Andrew. Memes of Translation: The Spread of Ideas in Translation Theory. Amsterdam: John Benjamins, 1997.

Coelho, Bárbara Resende, and Igor Antônio Lourenço Da Silva. "Towards a Multimodal Methodology for the Analysis of Translated/Localised Games." Domínios de Lingu@gem, vol. 11, 2017, pp. 6-16. doi: https://doi.org/10.14393/DL28-v11n1a2017-1

Collins Dictionary. Free Online Dictionary, Thesaurus and Reference Materials, https://www.collinsdictionary.com/. Accessed on: 12 February 2020.

Dietz, Frank. "Issues in Localizing Computer Games." Perspectives in Localization, edited by Keiran J. Dunne, John Benjamins, 2006, pp. 121-134. doi: https://doi.org/10.1075/ata.xiii.10die Dunne, Keiran J. "Localization." The Routledge Encyclopedia of Translation Technology, edited by Chan Sin-Wai, Routledge, 2015, pp. 550-562.

Eurogamer.Pt. Brasileiros Contra Dobragem de Uncharted 3: Naughty Dog Voltará Atrás na Escolha?, 2011, http://www.eurogamer.pt/articles/2011-09-04-brasileiros-contra-dobragemde-uncharted-3. Accessed on: 02 Mar. 2020. 
Gabrielprimeiro. $\quad$ Uncharted 3 Parte 2 Dublado PT BR, https://www.youtube.com/watch?v=78_p4i-XRrY. Accessed on: 02 Mar. 2020.

Jiménez-Crespo, Miguel Á. Translation and Web Localization, Routledge, 2013. https://doi.org/10.4324/9780203520208

Kiraly, Don. C. Pathways to Translation: Pedagogy and Process, The Kent State University Press, 1995.

Koolstra, Cees M., Allerd L. Peeters, and Herman Spinhof. "The Pros and Cons of Dubbing and Subtitling." European Journal of Communication, vol. 17, no. 3, 2002, pp. 325-354. doi: http://dx.doi.org/10.1177/0267323102017003694.

Lucky Salamander. Uncharted 3: Drake's Deception - Parte 1: Nathan Moleque! [Playstation 4 - Playthrough PT-BR], https://www.youtube.com/watch?v=6b7ANab_954. Accessed on: 02 Mar. 2020.

Michaelis. Dicionários de Inglês Online, Editora Melhoramentos, 2009, http://michaelis.uol.com.br/moderno/ingles/index.php?lingua=ingles-por- tugues\&pala-vra=well. Accessed on: 02 Mar. 2020.

Ministério da Justiça. Classificação Indicativa, http://justica.gov.br/seus-direitos/classificacao. Accessed on: 21 November 2019.

O'hagan, Minako, and Carmen Mangiron. Game Localization: Translating for the Global Digital Entertainment Industry, John Benjamins, 2013. doi: https://doi.org/10.1075/btl.106

Newman, Jones. Playing Videogames, Routledge, 2004.

Newman, Rich. Cinematic Game Secrets for Creative Directors and Publishers, Elsevier, 2009. doi: https://doi.org/10.4324/9780203642900

Pym, Anthony. The Moving Text: Localization, Translation, and Distribution, John Benjamins, 2004. doi: https://doi.org/10.1075/btl.49

Ranyard, Dave, and Vanessa Wood. "Interview with Miguel Bernal-Merino." The Journal of Specialised Translation, vol. 11, 2009.

Robinson, Douglas. Becoming a Translator, Routledge, 2003. doi: https://doi.org/10.4324/9780203441138

Sandrini, Peter. Website Localization and Translation. In: MuTra: Mul- tidimensional Translation Conference Proceedings, Saarbrucken, pp. 131-138, 2005.

Shohat, Ella, and Robert Stam. Crítica da Imagem Eurocêntrica, translated by Marcos Soares, Cosac Naify, 2006/1994.

Souza, Ricardo Vinícius. "O Conceito de "Gameplay Experience” Aplicado à Localização de Games." Scientia Traductionis, no. 15, 2014, pp. 8-26. doi: https://doi.org/10.5007/19804237.2014n15p8

ESQUEDA, Marileide Dias; MELO, Bárbara Coelho. The uncharted territory in Uncharted 3: expectancy vs. Professional norms in translated games. Belas Infiéis, Brasília, v. 9, n. 4, p. 173-199, jul./set., 2020. e-ISSN: 2316-6614.

DOI: 10.26512/belasinfieis.v9.n4.2020.26449 
Souza, Ricardo Vinícius. "Venuti e os Videogames: O Conceito de Domesticação/Estrangeirização Aplicado à Localização de Games." In-Traduções, vol. 5, no. esp. Games e Tradução, 2013, pp. 51-67.

Souza, Ricardo Vinícius. "Video Game Localization: The Case of Brazil." Tradterm, vol 19, 2012, p. 289-326, 18 jun. 2012. doi: https://doi.org/10.11606/issn.23179511.tradterm.2012.47438

Sinxplaysbr. Uncharted 3 - Capitulo 1 - A Saga Continua - Dublado em português, 2013, https://www.youtube.com/watch?v=awqX4LKdwzw. Accessed on: 02 March 2020.

The Language Arquive. "Elan version 4.9.3," http://tla.mpi.nl/tools/tla-tools/elan. Accessed on 02 Mar. 2020.

Uncharted: Drake's Fortune, Playstation 3, developed by Naughty Dog, published by Sony Computer Entertainment, 2007.

Uncharted 2: Among Thieves, Playstation 3, developed by Naughty Dog, published by Sony Computer Entertainment, 2009.

Uncharted 3: Drake's Deception, Playstation 4, developed by Naughty Dog, published by Sony Computer Entertainment, 2011.

Uncharted: The Nathan Drake Collection, Playstation 4, developed by Naughty Dog, published by Sony Computer Entertainment, 2015.

Uncharted 4: A Thief's End, Playstation 4, developed by Naughty Dog, published by Sony Computer Entertainment, 2015.

Venuti, Lawrence. Escândalos da Tradução: Por uma Ética da Diferença, translated by Laureano Pelegrin, Lucinéia Marcelino Villela, Marileide Dias Esqueda, and Valéria Biondo, Edusc, 2002/1998.

Teixeira, Patrícia Vieira e. For New Game Standards: A Localização de Games no Brasil sob a Perspectiva do Analista e do Usuário, Unpublished BA thesis, Universidade Federal de Uberlandia, Uberlandia, 2015.

Wood, Vanessa, Sophie Krauss, and Fabio Ravetto. "Behind the Curtains of Buzz," presentation at the Localization Summit at the International Game Developers Conference, 2010 .

\footnotetext{
*An oral presentation (and publishing of the abstract) with the partial results of this study was given at ENTRAD 2016 (XII Brazilian Translation Forum and VI International Translation Forum), held by the Brazilian Association of Translation Researchers (ABRAPT) and the Translation Program of the Federal University of Uberlândia, on September 20th-23rd, 2016.

1 The terms 'electronic games', 'games', and 'video games' are used interchangeably in this paper, and so are 'players', 'users', and 'gamers'. 'Game' is an umbrella term referring to any type of game, but, as stated by Bernal-
} 
Merino, the term is frequently used in reference to a video game (or electronic game, digital game, computer game, etc.) and is thus very popular and well-understood by the general public, which comprises not only English speakers, but also users from other countries.

${ }^{2}$ YouTube gamers are owners of YouTube channels focused on posting content about video games, such as gameplays (popularly called "let's play" videos), reviews, news, etc.

${ }^{3}$ Souza says that the successful interaction between player and game, which he calls gameplay experience, is responsible for providing a fun and pleasing experience to the player ("O Conceito de Gameplay Experience"). According to the author, this concept arises from the interaction between the player and the game, i.e., how the player behaves in regard to the software's assets, objectives, challenges, strategies, choices, etc. This interaction triggers the player's cognitive and emotional reactions in a process that result in their entertainment when they eventually achieve the final objective of the game.

${ }^{4}$ Gamers usually publish their comments about games online (O'Hagan and Mangiron), which does not seem to happen often with users and readers of other types of text. Future studies could perhaps broaden the scope of this research, encompassing other areas of the translation market. With this approach, we do not mean to question the quality of game translation, but rather how its reception becomes more evident in the abundance of comments posted by players in several online sharing platforms. Besides, the analyses carried out in this study with the game Uncharted 3 are not aimed at making any generalizations regarding this type of translation.

5 According to the Michaelis Dictionary, 'barbada' is an informal term/slang that means a very easy task, or a competition that is easy to win. In the Collins Dictionary, it is translated in English as 'piece of cake'. Although it is classified as a general slang in Brazilian Portuguese, the word is considered to be a regional expression from the South of the country and is not widely known or used in other regions of Brazil.

${ }^{6}$ Term used for describing the native people of the State of Rio Grande do Sul, in the South of Brazil.

${ }^{7}$ Vulgar expression meaning 'fucking hell'.

${ }^{8}$ Variation of the term 'gaúcho' as explained in endnote 6.

${ }^{9}$ Sentence quoted from the PT-PT dubbing of the game, exhibiting features of the European Portuguese variation of the language, such as verb conjugation, style, and lexicon.

${ }^{10}$ Word in European Portuguese, meaning 'fool', 'stupid person'.

${ }^{11}$ Synonym with 'parvalhão'.

${ }^{12}$ Expression meaning 'to get out of'/'leave some place'.

${ }^{13}$ Synonym phrase to the one mentioned in endnote 12 .

${ }^{14}$ Game genre in which the player sees the action from a third or first person (FPS - First Person Shooter) with the objective of firing with their arsenal (O'Hagan and Mangiron).

\section{BIOGRAPHICAL NOTES}

Marileide Dias ESQUEDA - Associate professor, Universidade Federal de Uberlandia, Uberlandia, Minas Gerais. $\mathrm{PhD}$ and $\mathrm{MA}$ in Applied Linguistics from Universidade Estadual de Campinas. BA in Translation from Universidade Sagrado Coração. Universidade Federal de Uberlândia, Instituto de Letras e Linguística, Bacharelado em Tradução. Uberlandia, Minas Gerais, Brazil.

ORCID: https://orcid.org/0000-0002-6941-7926

Academic CV: http://lattes.cnpq.br/3341029625579574

E-mail: marileide.esqueda@ufu.br

Bárbara Coelho MELO - B.A in Translation (2017) from the Universidade Federal de Uberlândia. Autonomous researcher. Uberlândia, Minas Gerais, Brasil.

ORCID: https://orcid.org/0000-0003-2090-5969

Academic CV: http://lattes.cnpq.br/5560193212702014

E-mail: barbara.resende.coelho@gmail.com 